\title{
GLOBALIZACIÓN ECONÓMICA Y PRINCIPIOS TRIBUTARIOS
}

\author{
ECONOMIC GLOBALIZATION AND TAX PRINCIPLES
}

\author{
Clemente CHECA GonZÁlez
}

RESUMEN: Se analizan en este trabajo algunas de las principales consecuencias propiciadas por el fenómeno de la globalización económica, examinando con atención los beneficios o los perjuicios que la competencia fiscal entre Estados origina, para concluirse que ésta genera más consecuencias negativas que positivas, debiendo mencionarse entre aquéllas la degeneración que ha supuesto el alcance y contenido de los principios constitucionales aplicables en la esfera tributaria, en particular los de capacidad económica, igualdad, progresividad y legalidad.

Palabras clave: globalización económica, competencia fiscal entre Estados, principios tributarios, degeneración fiscal.
ABSTRACT: Are analyzed in this study some of the major consequences created by the economic globalization. It examines the benefits or harms of tax competition between States, and concludes that it produces more negative than positive effects. Among the most harmful consequences is the degeneration of the constitutional principles applicable in the area of taxation, in particular those of economic capacity, equality, progress and legality.

Descriptors: Economic Globalization, Tax Competition, Taxation Principles, Fiscal Degeneration. 


\section{BREVES CONSIDERACIONES GENÉRICAS SOBRE EL FENÓMENO DE LA GLOBALIZACIÓN ECONÓMICA}

Conocido es que los Estados, cada vez en mayor grado desde que la "globalización económica" es un hecho evidente e imparable, con la progresiva desaparición de las barreras a la libre circulación transfronteriza de producciones y capitales, como ha indicado Lamagrande, ${ }^{1}$ compiten entre sí por atraer en la mayor medida posible hacia su ámbito de potestad tributaria las actividades económicas cuyo sometimiento a gravamen permita sostener unas siempre crecientes necesidades de recursos, como han expuesto Orón Moratal, Ibáñez Marsilla y González Ortiz. ${ }^{2}$

Para ello, conscientes de la indiscutible importancia que en el vigente estadio de internacionalización ostenta la fiscalidad en la localización de las actividades económicas - aunque es cierto que el factor impositivo no es el único a tomar en consideración a estos efectos-, se muestran proclives a configurar un clima tributario que logre atraer aquéllas hacia sus correspondientes territorios, como han señalado, entre otros autores, Hagen y Sorensen y Ruibal Pereira, ${ }^{3}$ lo que ha generado que los Estados se conviertan en competidores para conseguir el mayor número de contribuyentes y atraer hacia su propio territorio un número importante de empresas, en palabras de García Luque. ${ }^{4}$

Ello puede terminar por agrandar la grieta de las diferencias relativas a la fiscalidad de los rendimientos procedentes de las distintas alternativas de ahorro e inversión mobiliaria, como ha puesto de relieve García Novoa, ${ }^{5}$ quien añade que la libre circulación de capitales y la libertad de

1 Lamagrande, "Los desafíos de la administración tributaria frente a la globalización”, $C T$, núm. 87, 1998.

2 Orón Moratal et al., Poder tributario y competencia fiscal: en especial el caso de La Rioja, Logroño, Instituto de Estudios Riojanos, 2003.

3 Hagen y Sorensen, "Taxation of the Self-employed under a Dual Income Tax", Towards a Dual Income Tax?, en Varios Autores, Londres, Kluwer, 1996; Ruibal Pereira, "Fraude y competencia fiscal desleal en el proceso de armonización europea", en Varios Autores, Temas de derecho penal tributario, Madrid, Barcelona, Marcial Pons, 2000.

4 García Luque, "La actividad financiera del Estado social globalizado. (La prevención de gastos públicos y el tributo de tercera generación)", $R E D F$, núm. 131, 2006.

5 García Novoa, "Reflexiones sobre la influencia de la globalización en los principios tributarios", Revista Argentina de Derecho Tributario, Universidad Austral Tax Law 
establecimiento de bancos e instituciones financieras, se conjuga con una evidente diversidad impositiva, lo que unido a la fácil deslocalización de las inversiones mobiliarias conduce a que el factor fiscal resulte determinante a la hora de escoger el destino del ahorro. ${ }^{6}$

El resultado final puede ser una tendencia de los distintos Estados a la desfiscalización competitiva del ahorro y la inversión mobiliaria, con lo cual la libertad de circulación de capitales puede acabar convirtiéndose en libertad para orientar inversiones más por criterios de orden fiscal que de orden estrictamente económico.

Así fue ya apuntado por Merino Jara, ${ }^{7}$ cuando escribió que la influencia de la fiscalidad sobre la localización de las empresas es evidente, al constituir uno de los factores decisivos a la hora de inclinarse por la implantación en un lugar u otro.

Y así, por ejemplo, lo han puesto también de relieve Martín López, ${ }^{8}$ quien ha indicado que la intención de los Estados de atraer hacia su territorio, a través del instrumento tributario, el mayor número posible de inversiones empresariales y de capital, coadyuva de forma significativa a que un segmento de tales inversiones se localicen en exclusiva atención a parámetros fiscales, y Gorosabel Rebolleda, ${ }^{9}$ quien ha señalado que la movilidad de los diferentes factores de producción alienta que éstos se localicen en países que ofrezcan mayor rentabilidad neta, incluida la fiscal.

Se genera así lo que E. Díaz, ${ }^{10}$ siguiendo a Sennet, denomina capitalismo de casino, esto es, aquel que se mueve donde sea buscando los

Review, La Ley, núm. 5. Este trabajo también está publicado en Varios Autores, Direitto Tributário Internacional, São Paulo, Quarter Latin, 2003.

6 A este respecto Califano, "Controlled Foreign Companies: esperienze tributarie nazionali e principi del Trattato", en Varios Autores, Lo stato della fiscalità nell'Unione europea. L'esperienza e l'efficacia dell'armonizzazione, Bologna, Ministero dell'Economia e delle Finanze, 2003, t. II, ha escrito que "l'incidenza del fattore fiscale sulle scelte strategiche delle imprese in ordine all'alocazione dei capital e alla localizzazione delle attività economiche, è destinato a divenire un fattore sempre più rilevante".

7 Merino Jara, "Fiscalidad y Unión Europea”, JT, t. III, 1996.

8 Martín López, Competencia fiscal perjudicial y ayudas de Estado en la Unión Europea, Valencia, Tirant lo Blanch, 2006.

9 Gorosabel Rebolleda, "El nuevo IRPF", RIF, núm. 83, 2007.

10 Díaz, E. "Estado de derecho y sociedad democrática", en Varios Autores, Constitución, Estado de las autonomías y justicia constitucional (Libro homenaje a Gumersindo Trujillo), Valencia, Tirant lo Blanch, 2005. 
beneficios más inmediatos, lo que nos conduce a plantearnos la bondad o maldad de la competencia fiscal entre Estados.

\section{COMPETENCIA FISCAL ENTRE ESTADOS ¿BENEFICIOSA O LESIVA?}

La respuesta a esta interrogante entiendo que debería ser positiva si estuviésemos en presencia de una auténtica y verdadera competencia fiscal entre Estados, ya que si la competencia, en general, es saludable para la actividad económica, también la misma podría considerarse de esta misma manera favorable cuando se aplica a la esfera fiscal.

En palabras de Bracewell-Mines: ${ }^{11}$ "si la competencia entre empresas e individuos es beneficiosa, casi sin excepción ¿por qué la competencia entre Estados puede ser nociva?".

Así lo han indicado también, entre otros autores, Maldonado GarcíaVerdugo, Rhan y Rugy, Martín López ${ }^{12}$ — quien ha puesto de relieve que una ideal presión competitiva constreñiría a los distintos Estados a establecer un equilibrio entre la oferta de servicios públicos y el nivel de imposición, implicando, de un lado, una mayor eficiencia del gasto público y, de otro, la neutralización de la estéril sobredimensión que suelen presentar las administraciones públicas-y Chico de la Cámara; ${ }^{13}$ éste ha señalado que la competencia fiscal "sana" produce efectos económicos eficientes para los Estados miembros al mantener unos niveles moderados de gasto público; al lograr un equilibrio razonable entre la presión fiscal de los contribuyentes y el nivel de servicios públicos e infraestructuras sociales, así como al propiciar un menor coste de producción, fruto de la reducción de la presión fiscal, para las empresas que operan no sólo en mercados nacionales sino también internacionales.

11 Bracewell-Mines, "Tax Competition: Harmful or Beneficial”, Intertax, núm. 3, 1999.

12 Maldonado García-Verdugo, "Ejercicios sobre competencia fiscal perjudicial en el seno de la Unión Europea y de la OCDE: semejanzas y diferencias", CT, núm. 97, 2001; Rhan y Rugy, "Threats to Financial Privacy and Tax Competition", Policy Analysis, núm. 10, 2003; Martín López, op. cit., nota 8.

13 Chico de la Cámara, “¿Competencia fiscal 'lesiva' o ‘beneficiosa’?: un argumento adicional para la armonización de la imposición directa de los no residentes”, $R C T$, núm. 280, 2006. 
Y en la misma línea de, entre otras, las sentencias del Tribunal de Justicia de las Comunidades Europeas de 28 de abril de 1998, As. C-118/96, Jessica Safir contra Skattemyndigheten i Dalarnas län, antes Skattemyndigheten i Kopparbergs län, y 3 de octubre de 2002, As. C-136/00, Rolf Dieter Danner, se desprende, como han escrito Martín Jiménez y Calderón Carrero, ${ }^{14}$ que la "competencia fiscal" entre Estados forma parte o está implícita en la idea del mercado interior.

El admitir esta competencia podría fundarse, por lo demás, y salvando las distancias, en la circunstancia de que en la esfera privada se admite de forma plena la planificación fiscal — “economía de opción”, en palabras de Larraz- ${ }^{15}$ considerándola como un comportamiento lícito, como una actividad legítima, en palabras de González García, ${ }^{16}$ que se distingue de forma clara de la evasión fiscal, ya que los contribuyentes tienen derecho a organizar sus negocios de la forma que le resulte más económica, también desde el punto de vista tributario, no estando obligados a anteponer los intereses del fisco a los suyos propios.

Así se ha declarado por la jurisprudencia en múltiples ocasiones. Concluyente en esta línea, aparte del texto histórico de la Suprema Corte Americana, en el caso Helvering vs. Gregory, citado por Vilar Mayer y por Godoi, ${ }^{17}$ en el que se afirmó:

Cada uno tiene el derecho de organizar sus asuntos de negocio de una manera tal que lleven la carga tributaria al mínimo; nadie debe planear sus costos y renta a la conveniencia máxima de la hacienda; para un ciudadano no hay ningún deber patriótico que le obligue a aumentar sus propios pagos del impuesto. ${ }^{18}$

14 Martín Jiménez y Calderón Carrero, “Jurisprudencia del Tribunal de Justicia de las Comunidades Europeas en materia de IRPF", en Varios Autores, Manual del Impuesto sobre la Renta de las Personas Físicas, Madrid, IEF, 2005.

15 Larraz, "Metodología aplicativa del derecho tributario, Revista de Derecho Privado, Madrid, 1952.

16 González García, El fraude a la Ley Tributaria en la jurisprudencia, Navarra, Aranzadi, 2001.

17 Vilar Mayer, "Planificación fiscal indebida y el conflicto en la aplicación de la norma tributaria española", RCT, núm. 273, 2005; Godoi, Fraude a la ley y conflicto en la aplicación de las leyes tributarias, Madrid, IEF, 2005.

18 Sentencia del Tribunal de Justicia de las Comunidades Europeas de 21 de febrero de 2006, As. C-255/02, Halifax plc, Leeds Permanent Development Services Ltd, County Wide Property Investments Ltd y Commissioners of Customs \& Excise. 
En dicha sentencia se declaró que cuando un sujeto pasivo puede elegir entre dos operaciones, la normativa comunitaria no le obliga a optar por la que maximice el pago del impuesto, sino que, al contrario, el sujeto pasivo tiene derecho a elegir la estructura de su actividad más conveniente para reducir su deuda fiscal, con el único límite de que ello no suponga prevalerse de las normas de forma abusiva o fraudulenta.

Se recogió así en esta sentencia la visión del abogado general Poiares Maduro, que en el punto 85 de sus conclusiones a este litigio, presentadas el 7 de abril de 2005, había afirmado:

- Que los sujetos pasivos pueden optar por estructurar su negocio con objeto de limitar su responsabilidad tributaria.

- Que no existe obligación legal de gestionar una empresa de modo que se maximice el ingreso fiscal para el Estado.

- Que el principio básico es la libertad de optar por el medio menos gravado de gestionar la empresa para reducir los costes al mínimo, especificando que el pago de impuestos es un coste que un operador económico puede tener de manera legítima en cuenta, siempre que cumpla las obligaciones fiscales que le incumben, al elegir entre las diversas opciones de gestionar su empresa, pudiendo ciertas personas albergar dudas sobre la moralidad de esa libertad, pero no sobre su legalidad. ${ }^{19}$

Al ser esto así y, reitero, salvando la diversa posición en la que se encuentran los Estados y los obligados tributarios, bien podría convenirse que cuando aquéllos emplean las armas de la competencia fiscal lo que

19 Lo propio se ha afirmado en el derecho interno español, constituyendo buen ejemplo de ello, entre otras, las sentencias del Tribunal Supremo de 30 de marzo de 1999, 15 de julio de 2002, 2 de noviembre de 2002, 28 de noviembre de 2003, 11 de mayo de 2004, 14 de marzo de 2005, 21 de marzo de 2005 y 22 de marzo de 2005, en las que se ha afirmado que la "economía de opción", o "estrategia de minoración de coste fiscal", fundada en el principio de autonomía de voluntad, en la libertad de contratación establecida en el artículo 1255 del Código Civil, produce un ahorro fiscal a las partes que no resulta contrario al ordenamiento jurídico. Y las sentencias de la Audiencia Nacional de 3 de octubre de 1997 y 6 de mayo de 2004, en las que se ha declarado que el ahorro de impuestos es uno más de los motivos lícitos que influyen en las decisiones de todos los contribuyentes, por lo que la motivación fiscal no es, ni puede ser, por sí misma condenable. 
en el fondo están haciendo es utilizar las normas dictadas con este fin para conseguir, simple y sencillamente, una posición que les beneficie a ellos, no pudiéndoseles obligar a que prioricen otros intereses en detrimento de los suyos propios y particulares.

Dicho esto, entiendo, con Martín López, ${ }^{20}$ que la competencia fiscal entre Estados muestra un perfil asimétrico, al restringir su ámbito de actuación a la captación de factores dotados de una inherente movilidad.

Y en similar línea McLure, $\mathrm{Jr}^{21}$ ha escrito que:

El hecho de que algunas formas de competencia fiscal puedan ser beneficiosas no significa que todas sus formas también lo sean. A diferencia de la competencia relativa a actividades económicas reales, que dependen de las diferencias en los tipos efectivos (marginales o medios) de gravamen y puede tener efectos saludables, la competencia sobre la base imponible no conectada a una actividad económica real, que depende de las diferencias en los tipos impositivos legales, es probable que no sea beneficiosa, porque crea externalidades fiscales negativas, erosionando los ingresos fiscales de todas las naciones, especialmente de aquellas que tienen tipos nominales elevados, y desplazan rendimientos desde las naciones con elevada fiscalidad a las de fiscalidad reducida...

Incentivando el desplazamiento de rentas a través de la manipulación de precios de transferencia y de estructuras financieras. ${ }^{22}$

Estimo, por todo ello, que esta competencia desleal sí es rechazable y tiene que hacerse frente a la misma, para lo cual puede utilizarse la propia argumentación del Tribunal de Justicia de Luxemburgo.

20 Martín López, op. cit., nota 8.

21 Mclure, Jr., Método legislativo, judicial, de soft law y cooperativo para armonizar los impuestos sobre sociedades en los Estados Unidos y en la Unión Europea, Civitas, REDF, núm. 136, 2007.

22 Así se indicó también en el documento sobre la fiscalidad en la Unión Europea debatido por los ministros de Economía y Hacienda el 13 de abril de 1996 en Verona - SEC (96) 487_, en el que se afirmó que si bien la competencia leal es un componente clave del mercado único, la competencia desleal, en cambio, es preocupante en el ámbito fiscal por sus potenciales efectos negativos, en particular sobre los ingresos fiscales de los Estados miembros, sobre la eficiente asignación de los recursos económicos en la Unión Europea, y sobre la competitividad y el empleo. Y añadió que la disminución de ingresos fiscales podía producirse o por la fuga de bases imponibles a otros Estados o por la fuga de bases imponibles hacia la economía sumergida, dependiendo la primera del diferencial de tipos de gravamen, y la segunda de su nivel absoluto. 
Y esto es así porque si bien es cierto, como ya antes se dijo, que el mismo ha admitido que no puede obligarse a un contribuyente a tener que optar por la alternativa fiscal más gravosa para él y que, por consiguiente, puede seguir la senda que le sea más rentable desde esta perspectiva tributaria, también ha señalado, sin embargo, que ello es así siempre que no suponga prevalerse de las normas de forma abusiva o fraudulenta. ${ }^{23}$

En suma, como también ha manifestado el Tribunal de Justicia de las Comunidades Europeas, la aplicación del derecho comunitario no puede extenderse hasta llegar a cubrir las prácticas abusivas de los operadores económicos, esto es, las operaciones que no se realicen en el marco de transacciones comerciales normales, sino sólo para beneficiarse en exclusiva de las ventajas establecidas en el derecho comunitario. ${ }^{24}$

Cabe considerar, por esto, que cuando un Estado dicta normas fiscales con el exclusivo objeto de atraer inversiones y capital a su territorio lo que en realidad está haciendo es buscar, de forma deliberada, una posición de preminencia frente a otros Estados, empleando para ello unas prácticas abusivas que van más allá, distorsionándolas de manera interesada, de las sanas reglas de competencia que debe regir las relaciones entre todos ellos. ${ }^{25}$

23 Así se deduce de la lectura de, entre otras, sus sentencias de 12 de mayo de 1998, As. C-367/96, Alexandros Kefalas y otros contra Elliniko Dimosio (Estado helénico) y Organismos Oikonomikis Anasygkrotisis Epicheiriseon AE (OAE); de 23 de marzo de 2000, As. C-373/97, Dionysios Diamantis contra Elliniko Dimosio y Organismos Oikonomikis Anasygkrotisis Epicheiriseon AE (OAE), y de 3 de marzo de 2005, As. C-32/03, I/S Fini H contra Skatteministeriet.

24 Así se ha declarado, en particular, en sus sentencias de 11 de octubre de 1977, As. 125/76, Entreprise Peter Cremer contre Bundesanstalt für landwirtschaftliche Marktordnung; de 3 de marzo de 1993, As. C-8/92, General Milk Products contra Hauptzollamt Hamburg-Jonas, y de 14 de diciembre de 2000, As. C-110/99, Emsland-Stärke GmbH contra Hauptzollamt Hamburg-Jonas.

25 Estimo, además, siguiendo a Grau Ruiz y Herrera Molina, "La armonización fiscal: límites y alternativas", Impuestos, 2002, t. I, que el propio término "competencia fiscal" es engañoso, pues no existe un auténtico "mercado" en el que actúen de forma libre las fuerzas de la oferta y de la demanda en interés de la eficiencia en la producción y distribución de bienes y servicios, sino un juego de intereses políticos y económicos perjudicial para aquellas rentas carentes de auténtica movilidad. 
Muestras significativas de este criticable proceder fruto de referida competencia fiscal perniciosa, aunque no las únicas, son, a título de mero ejemplo, las siguientes:

- La manera de gravar las rentas del capital, manifestación ésta de capacidad económica en especial volátil y susceptible de "deslocalización", para evitar lo cual no pocos Estados han convenido que lo más idóneo era sujetarlas a menor tributación que al resto de rendimientos, y así lo han hecho mediante el establecimiento de reducidos tipos proporcionales para estas rentas.

- La práctica seguida por determinados Estados de atraer tejido empresarial sirviéndose para ello, como han apuntado Gutiérrez Lousa y Rodríguez Ondarza. ${ }^{26}$

O bien de las oportunas reducciones de tipos de gravamen en los impuestos que gravan la renta de las personas físicas o de las entidades.

$\mathrm{O}$ incluso de la introducción, con este mismo objetivo, de una amplia serie de estímulos, incentivos fiscales y regímenes especiales y preferenciales, como también han denunciado Enrich, Rolle, García Prats, Ferreiro Lapatza y Cruz Padial, ${ }^{27}$ dictados para atraer inversiones financieras y empresariales a sus territorios, conscientes como son, según han señalado Avi-Yonah y Caamaño Anido y Calderón Carrero, ${ }^{28}$ de que los inver-

26 Gutiérrez Lousa y Rodríguez Ondarza, Las consecuencias fiscales de la globalización, IEF, doc. núm. 8, 2007.

27 Enrich, "Saving the States from themselves: commerce clause constraints on state tax incentives", Harward Law Review, núm. 2, 1996; Rolle, "Mercato interno e fiscalità diretta nel Trattato di Roma e nelle recenti iniziative della Commissione europea", Diritto e Pratica Tributaria, núm. 2, 1999; García Prats, "Incidencia del derecho comunitario en la configuración jurídica del derecho financiero (II): políticas comunitarias con incidencia sobre el derecho financiero", RDFHP, núm. 260, 2001; Ferreiro Lapatza, "Simplificación; base imponible y renta empresarial”, $Q F$, núm. 21, 2006, y Cruz Padial, "Sistema tributario: su falta de adecuación al contexto actual originado por el proceso de globalización económica”, $N F$, núm. 9, 2007.

28 Avi-Yonah, "Globalisation, Tax Competition, and the Fiscal Crisis of the Welfare State", Harvard Law Review, vol. 113, núm. 7, 2000, y Caamaño Anido y Calderón Carrero, "Globalización económica y poder tributario: ¿hacia un nuevo derecho tributario?", $R E D F$, Civitas, núm. 114, 2002. 
sores tienden a localizar su capital e inversiones empresariales en el lugar donde perciben una mayor rentabilidad financiero-fiscal. ${ }^{29}$

Ante estas situaciones, aquellos Estados que no hayan adoptado una postura tan "agresiva", por emplear la expresión de Maldonado GarcíaVerdugo (2001), se ven compelidos y avocados a defender sus bases imponibles, esquilmadas y erosionadas, en palabras de Chico de la Cámara (2006), para lo que parece que no les ha quedado más remedio que reducir de forma selectiva sus niveles de gravamen, conscientes de que de no obrar así se produciría, casi de forma indefectible, una minoración de los flujos de capital e inversión en su economía, como ha escrito Cordero González. ${ }^{30}$

Con este objetivo se ha instrumentado, como han puesto de relieve Calderón Carrero y Martín López, ${ }^{31}$ una carrera de sucesivas reducciones fiscales, race to the bottom, articuladas por los poderes ejecutivos y refrendadas por los respectivos legislativos, que han recibido directrices concretas en este sentido acerca de la inevitabilidad de esta forma de actuar en un mundo en el que las interrelaciones son muy evidentes y fuertes, cumpliéndose así lo que ya había apuntado Orón Moratal ${ }^{32}$ cuando, refiriéndose a estas cuestiones, escribió que la imposición directa sobre el capital y actividades económicas podía entrar en una espiral descendente a partir de una decisión de un Estado que provocase reflejos en otros, con el objetivo de no desvirtuar el mercado, entrando en una competencia "a la baja" — expresión que también emplea Martínez García-

29 Como ha escrito Santacroce, "La política di concorrenza nella UE", en Varios Autores, Lo stato della fiscalità nell'Unione europea. L'esperienza e l'efficacia dell'armonizzazione, cit., nota 6, t. II, 2003: "In questo contesto resulta più semplice comprendere come le imprese possano utilizzare la leva fiscale per rendere più competitiva la loro azioni sul mercato, scegliendo tra ordinamenti diversi e sfruttando a pieno le incongruenza e le piccole e grandi incompatibilità dei differenti sistema fiscali".

30 Cordero González, "El intercambio de información sobre las rentas del capital mobiliario en la Unión Europea", en Varios Autores, Estudios de derecho financiero y tributario en homenaje al prof. Calvo Ortega, Valladolid, Lex Nova, 2005, t. I.

31 Calderón Carrero, La incidencia de la globalización en la configuración del ordenamiento tributario del siglo XXI, IEF, doc. núm. 20, 2006 y Martín López, op. cit., nota 8.

32 Orón Moratal, "Consecuencias de la integración en las comunidades europeas sobre el derecho financiero y tributario”, REDF, Civitas, núm. 97, 1998. 
Moncó— ${ }^{33}$ que puede poner en dificultades el nivel de servicios públicos del correspondiente Estado en beneficio del mercado.

Es evidente a este respecto, por ceñirme a los dos ejemplos antes apuntados, que la tributación proporcional, y con tipos de gravamen reducidos de las rentas del capital, mediante la implantación del dual income tax, conduce a una inequitativa forma de trato entre ésta y las otras rentas, como ya puso de relieve Tanzi, ${ }^{34}$ lo que conlleva un fuerte correctivo a la idea de justicia, como, entre otros autores, han denunciado Cubero Truyo, Villar Ezcurra, Barquero Estevan y Patón García. ${ }^{35}$

$\mathrm{O}$ que el benigno trato fiscal dispensado a las rentas empresariales debido de manera principal, aunque no exclusiva, a la abusiva utilización de regímenes especiales y beneficios fiscales, genera un atentado a la defensa de los intereses públicos, ya que estas medidas están, en general, dirigidas, como ya en su momento escribió Martín Queralt, ${ }^{36}$ no a tutelar intereses generales, sino a garantizar la satisfacción de apetencias más o menos minoritarias que, por ello, no favorecen a "los contribuyentes" sino a "ciertos contribuyentes".

Este proceder configura uno de los más importantes semilleros de desigualdad y privilegios, ${ }^{37}$ y desencadena un proceso - que ya por algunos autores, como Avi-Yonah, Wolf, Owens y Lodin, ${ }^{38}$ ha sido calificado de

33 Martínez García-Moncó, Libre circulación de capitales en la Unión Europea: problemas tributarios, Madrid, Civitas, 1999.

34 Tanzi, Taxation in a Integrating World, Washington, IMF, 1995.

35 Cubero Truyo, "La función del I.R.P.F. en el sistema tributario según la jurisprudencia constitucional", RIF, núm. 27, 1998; Villar Ezcurra, "Exigencias del derecho comunitario a la metodología del derecho financiero y tributario", $C T$, núm. 100, 2001; Barquero Estevan, La función del tributo en el Estado social y democrático de derecho, Madrid, Centro de Estudios Políticos y Constitucionales, 2002 y Patón García, "Consideraciones acerca de la justicia financiera en los albores del siglo XXI", en Varios Autores, Estudios jurídicos en memoria de Don César Albiñana Garcia-Quintana, Madrid, IEF, 2008, vol. II.

36 Martín Queralt, “Constitución Española y derecho financiero”, HPE, núm. 63, 1980 .

37 Véase Ferreiro Lapatza (dir. y coord.), La justicia tributaria en España, Madrid, Marcial Pons, 2005.

38 Avi-Yonah, op. cit., nota 27; Wolf, "Does globalisation render States Impotent?", British Tax Review, núm. 5, 2000; Owens, "Tax Systems in the New Millennium”, Liber 
fiscal degeneration, o de fiscal degradation, en palabras de Easson-, 39 de imprevisibles e impredecibles consecuencias, y que ya ha conducido, según ha indicado Casado Ollero, ${ }^{40}$ a que cada vez más estemos en presencia no ya de un Estado de derecho fiscal sino de un mercado de derecho fiscal, al sentirse condicionado el legislador de manera muy intensa por los márgenes de maniobra que le permite el mercado. ${ }^{41}$

Todo esto también ha supuesto una minusvaloración de los principios constitucionales tributarios, de índole sustantiva y formal, tal como éstos han sido tradicionalmente concebidos, según paso a exponer.

\section{LA DEGRADACIÓN DEL ALCANCE Y CONTENIDO}

DE LOS TRADICIONALES PRINCIPIOS APLICABLES EN LA ESFERA FISCAL COMO CONSECUENCIA DE LOS FACTORES APUNTADOS

El conjunto de las circunstancias mencionadas ha generado ya graves perjuicios, algunos de los que ya se están poniendo de forma muy clara de manifiesto, como sucede por ejemplo con la conculcación que ello supone de los principios constitucionales tributarios.

Es evidente, ha escrito Calderón Carrero, ${ }^{42}$ que la política fiscal nacional o la configuración del ordenamiento tributario está cada vez más condicionada por movimientos internacionales, o por consideraciones de competitividad internacional, y mucho menos por criterios o fundamentos relacionados con referidos principios, bastantes de los cuales se están convirtiendo en un mero artificio retórico sin contenido alguno.

Amicorum Sven-Olof Lodin, Kluwer, The Hague, 2001, y Lodin, "The Competitiveness of EU Tax Systems", European Taxation, mayo de 2001.

39 Easson, "Fiscal Degradation and the Inter-nation Allocation of Tax Jurisdiction", EC Tax Review, 1996-3, Kluwer, The Netherlands, 1996.

40 Casado Ollero, “Ámbito de aplicación de los principios de justicia tributaria”, en Varios Autores, Memorias de los seminarios de derecho constitucional tributario 20052006, México, Suprema Corte de Justicia de la Nación, 2007.

41 Similar afirmación se ha mantenido, asimismo, desde una óptica más general, por De Vega, "Mundialización y derecho constitucional: la crisis del principio democrático en el constitucionalismo actual", REP, núm. 100, 1998, cuando señaló que el proceso de mundialización está aniquilando de forma aparatosa las realidades constitucionales de los distintos Estados.

42 Calderón Carrero, op. cit., nota 30. 
Con ello, como bien ha escrito García Novoa: ${ }^{43}$

La fiscalidad, lejos de aparecer gobernada por criterios de justicia impositiva, es tomada en consideración exclusivamente como un elemento que puede provocar discriminaciones o atentar contra la libre circulación de capitales o la libertad de establecimiento.

Es notorio que la justicia fiscal es, en buena medida, un concepto etéreo. Con todo, pese a la evidente relativización de la noción de justicia, en general, y de la tributaria, en particular, parece evidente que obrando de la manera expuesta en las páginas precedentes los poderes públicos desconocen de modo flagrante, como se declaró, a guisa de ejemplo, por la Sentencia del Tribunal Constitucional español 182/1997, de 28 de octubre, que:

...existe el deber de pagar el impuesto de acuerdo con la capacidad económica en el modo, condiciones y cuantía establecidos por la ley; pero existe, correlativamente, un derecho a que esa contribución de solidaridad sea configurada en cada caso por el legislador según aquella capacidad.

Ello, desde luego, no se aprecia en modo alguno cuando, a igualdad de capacidad económica o aún, que es lo más probable, a mayor capacidad económica en el supuesto de quienes obtienen rendimientos de capital mobiliario, se dispensa a los mismos un más benigno tratamiento tributario que a los perceptores de otras clases de renta. Ello supone no tratar igual a los iguales, al no otorgarse el mismo trato a dos contribuyentes con niveles iguales de capacidad impositiva pero con rendimientos procedentes de distintos orígenes.

Se ha justificado esta grave anomalía con la difusa razón de que no se puede mirar para otro lado si se forma parte de un mundo globalizado que marca las pautas, tal como ha escrito Fernández Junquera. ${ }^{44}$

Este argumento economicista, que recuerda la queja de un famoso polígrafo griego que señaló que hay quien ajusta las leyes a las cosas más que las cosas a las leyes, y que es utilizado por gobiernos de todas las

43 García Novoa, op. cit., nota 5.

44 Fernández Junquera, "El IRPF y los principios constitucionales de justicia tributaria: una relación controvertida", en Varios Autores, Estudios jurídicos en memoria de don César Albiñana García-Quintana, Madrid, IEF, 2008, vol. II. 
tendencias, como ha escrito Xiol Ríos, ${ }^{45}$ implica reducir a escombros la construcción de la noción de justicia tributaria plasmada en los textos constitucionales.

A la vista de todo ello, se hace también en verdad difícil seguir sosteniendo, como de manera acrítica ha hecho el Tribunal Constitucional español en diversas ocasiones - véase, por ejemplo, sus sentencias 134/1996, de 22 de julio; 182/1997, de 28 de octubre; 46/2000, de 17 de febrero; 47/2001, de 15 de febrero; 137/2003, de 3 de julio y 108/2004, de 30 de junio - que es a través del Impuesto sobre la Renta de las Personas Físicas como se realiza la personalización del reparto de la carga fiscal en el sistema tributario según los criterios de capacidad económica, igualdad y progresividad, lo que lo convierte en una figura impositiva primordial para conseguir que nuestro sistema tributario cumpla los principios de justicia tributaria que impone el artículo 31.1 de la Constitución; que este tributo es el instrumento más idóneo para alcanzar los objetivos de redistribución de la renta y de solidaridad que la Constitución española propugna en sus artículos 131.1 y 138.1; y que este impuesto es, sin duda alguna, aquel en el que el principio de capacidad económica encuentra una más cabal proyección.

La terca realidad demuestra, sin embargo, que este impuesto ha perdido en los momentos presentes gran parte de las virtudes que en otro momento hicieron exclamar a buena parte de la doctrina que el mismo tenía un prestigio o una legitimidad, en términos de su aceptación social, que lo habían convertido en el principal protagonista del sistema impositivo, colaborando de forma muy eficaz a formar la conciencia colectiva de los ciudadanos.

Estas afirmaciones en la actualidad carecen, en buena medida, de apoyo, como bien ha resaltado Casado Ollero, ${ }^{46}$ quien ha escrito

que la función que (en el dogma) estuvo llamado a cumplir el impuesto, no coincide con lo que (en la norma) logró plasmar el legislador en la historia

45 Xiol Ríos, "Legitimidad y legalidad en la sociedad española del siglo XXI", en Varios Autores, Parlamento y Poder Judicial. XIII Jornadas de la Asociación Española de Letrados de Parlamentos, Madrid, Tecnos, 2007.

46 Casado Ollero, "Deber de contribuir e Impuesto sobre la Renta de las Personas Físicas en la jurisprudencia constitucional", en Varios Autores, Manual del Impuesto sobre la Renta de las Personas Físicas, Madrid, IEF, Escuela de la Hacienda Pública, 2005. 
del Impuesto sobre la Renta de las Personas Físicas y aún menos con lo que la realidad ha terminado asignándole en el sistema tributario vigente.

Siguiendo en la misma línea, otro buen ejemplo de lo denunciado es lo que ocurre con el principio de progresividad, que ya no es más una cáscara vacía, por haberse ido diluyendo sus exigencias hasta hacerlo irreconocible, como ha indicado Fabra Valls. ${ }^{47}$

Esto es fácil de comprobar de manera muy simple y sencilla observando, en el seno del ordenamiento tributario español, que dos de los tres principales impuestos del mismo: el Impuesto sobre Sociedades y el Impuesto sobre el Valor Añadido, se rigen por tipos proporcionales, y que el tercer pilar de esa triada: el Impuesto sobre la Renta de las Personas Físicas, ha abandonado ya la progresividad para el gravamen de las de forma eufemística denominadas "rentas del ahorro", existiendo, además, en todos ellos, un amplio cúmulo de deducciones y de regímenes especiales que contribuyen también, en buena medida, a atenuar inclusive la misma configuración proporcional.

Cierto es que el principio de progresividad se predica del sistema tributario en su conjunto, no de cada uno de los tributos en particular, por lo que es constitucional que existan impuestos proporcionales. ${ }^{48}$

Si se tiene presente, sin embargo, el dato ya mencionado de que los principales tributos existentes en España son proporcionales en todo, o

47 Fabra Valls, "Solidaridad y derecho financiero en una sociedad neocompetitiva", REDF, Civitas, núm. 120, 2003.

48 Sobre ello nada cabe objetar. Es más, comparto la opinión de Tipke, "El derecho tributario constitucional en Europa", Revista Euroamericana de estudios tributarios, núm. 5,2000 , de que el principio de capacidad económica no exige la progresividad del gravamen, habiendo ya antes escrito a este respecto Rodríguez Bereijo, "El sistema tributario en la Constitución (los límites del poder tributario en la jurisprudencia del Tribunal Constitucional)", $R E D C$, núm. 36, 1992, que el principio de progresividad no tiene suficiente fuerza como para poder afirmar que la tributación proporcional no responde también al principio de capacidad económica. Y, de forma más contundente aún, Eisenstein, Las ideologías de la imposición, Madrid, IEF, 1983 ya había afirmado que todos deberían soportar la misma alícuota tributaria, especificando que si los pobres no deben sufrir peor trato que los ricos, tampoco a los ricos hay que tratarlos peor que a los pobres, sino que todos deben ser gravados de forma similar, tesis que justificó Adam Smith en la obra Investigación sobre la naturaleza y causas de la riqueza de las naciones, de cuya doctrina en materia de cánones o máximas de la imposición se deduce, de forma inequívoca, que el principio de capacidad de pago es sinónimo de imposición proporcional. 
en una parte significativa, se me antoja en verdad difícil alcanzar a comprender cómo el sistema pueda llegar a ser progresivo en su conjunto cuando las partes esenciales del mismo, tanto desde la óptica cualitativa como por la recaudación que con ellas se obtiene, no lo son.

Por ello, de nuevo nos volvemos a encontrar con una palmaria contradicción, otra más, entre el mandato de la Constitución española que sí quiso un sistema progresivo - porque sus redactores estaban, es muy probable, imbuidos del "mito de la progresividad a toda costa", de que habló Fantozzi- ${ }^{49}$ y lo establecido en las leyes reguladoras de los concretos impuestos del ordenamiento tributario español, que dispensan escasa estima a dicho principio de progresividad. ${ }^{50}$

Es, además, evidente e incontestable que la progresividad del Impuesto sobre la Renta de las Personas Físicas español se cimenta, en exclusiva, en las rentas del trabajo.

Ello está propiciado por la competencia fiscal perjudicial ya antes aludida, ya que si como consecuencia de ella y debido al elevado grado de movilidad de determinadas bases tributarias los Estados, como ya se

49 Fantozzi, "Il sistema tributario tra libertà di iniziativa económica e solidarietà sociale", Dir. ec., núm. 3, 1994.

50 Esto quizá ha sucedido, en el afán de buscar alguna explicación a este fenómeno, porque en un plano abstracto es muy difícil determinar hasta dónde puede ir la progresividad sin incurrir en contraste con la prohibición de la confiscatoriedad que, de conformidad con lo señalado, por buena parte de la doctrina — entre otros autores Lejeune Valcárcel, "Aproximación al principio constitucional de igualdad tributaria", en Varios Autores, Seis estudios sobre derecho constitucional e internacional tributario, Madrid, Derecho Financiero, 1980; Jiménez Ambel, "El alcance confiscatorio como límite del sistema tributario español", $R V H P$, núm. 7, 1989; Ruiz-Huerta Carbonell, "Vigencia y operatividad del principio de la no confiscatoriedad de los tributos en el ordenamiento español", CT, núm. 64, 1992; Miranda Pérez, "El principio constitucional de no confiscatoriedad en materia fiscal", JT, 1997, t. III; Varona Alabern, "Temas selectos sobre el ámbito de aplicación de los principios de justicia tributaria", en Varios Autores, Memorias de los seminarios de derecho constitucional tributario 2005-2006, cit., nota 40, y Moreno Fernández, "Del deber constitucional de pagar un tributo a la responsabilidad patrimonial del Estado-legislador", El Cronista del Estado Social y Democrático de Derecho, núm. 3, 2009-, no sería sino la expresión de un límite a la progresividad del sistema tributario. Ello implica el nacimiento de una cierta contradicción, ya que, por un lado, los impuestos progresivos parecen imponerse en la Constitución española como medios adecuados para el logro de la igualdad real y efectiva, y, por otro, se reconoce que una elevada progresividad podría incurrir en inconstitucionalidad por producir resultados tachados de confiscatorios. 
indicó, han procedido a reducir la carga impositiva de las mismas, para intentar evitar su deslocalización, para mantener en un nivel aceptable su recaudación se han visto forzados a incrementar, en la misma medida, la imposición sobre bases menos móviles, esto es, sobre tales rentas del trabajo, como han criticado numerosos autores - véase a título de mero ejemplo Owens, De Kam y Clark, Avi-Yonah, Carrasco González, Magraner Moreno y Martín López, Almudí Cid, Arana Landín y Fernández Orte — ${ }^{51}$ con los problemas de constitucionalidad (conflictos con los principios de igualdad y redistribución de la renta) que ello supone, como han expresado Caamaño Anido y Calderón Carrero. ${ }^{52}$

Esta situación, se mire como se mire $-\mathrm{y}$ sin que constituya ningún consuelo la circunstancia de que ocurra lo mismo en la mayoría de los países avanzados, en los que también los impuestos que gravan la renta de las personas físicas se han convertido en tributos que recaen, en esencia, sobre las rentas salariales, que son las que soportan la mayor presión fiscal efectiva - no deja de ser una palmaria y concluyente vulneración de la justicia tributaria ${ }^{53}$ reclamada por en el caso español por el artículo

51 Owens, "Emerging Issues in Tax Reform: the Perspective of an International Bureaucrat", Tax Notes International, vol. 15, núm. 25, 1997; De Kam y Clark, “A World of Taxes: the OECD Reports on Tax Trends", Tax Notes International, vol. 16, núm. 12, 1998; Avi-Yonah, op. cit., nota 27; Carrasco González, El principio democrático de autoimposición en la producción normativa de la Unión Europea, Valencia Tirant lo Blanch, 2005; Magraner Moreno y Martín López, "Normativa comunitaria en ayudas de estado versus competencia fiscal perjudicial", Cuadernos de Integración Europea, núm. 4, 2006; Almudí Cid, "Planificación fiscal internacional a través de sociedades holding", $I E F$, doc. núm. 24, 2006; Arana Landín, "Los pretendidos principios de simplificación y neutralidad como justificación de base en las distintas reformas del IRPF", Nueva Fiscalidad, núm. 2, 2007, y Fernández Orte, "El principio de capacidad económica y el nuevo IRPF", RTT, núm. 80, 2008.

52 Caamaño Anido y Calderón Carrero, op. cit., nota 27.

53 Así se han pronunciado también, entre otros autores, Navas Vázquez, "Algunos fallos del sistema tributario", Estudios jurídicos en memoria de don César Albiñana García-Quintana, cit., nota 44, quien ha escrito que no se puede seguir sosteniendo, a modo de cliché, que el Impuesto sobre la Renta de las Personas Físicas es el que mejor sirve a la consecución de la justicia tributaria, ya que este tributo, como manifestó en otro trabajo "Sistema tributario", $Q F$, núm. 6, 2008, ha dejado de jugar un papel eficaz en la consideración equitativa de la capacidad económica; y Bustos Gisbert y Artés Caselles, "Una valoración de la última reforma del Impuesto sobre la Renta de las Personas Físicas", Justicia y derecho tributario, Libro homenaje al prof. Julio Banacloche Pérez, Madrid, La Ley, 2008, quienes han indicado que la vigente regulación de este impuesto genera 
31.1 de la Constitución, que extiende su exigencia a todos y cada uno de los tributos que conforman el sistema tributario, como ya hace tiempo indicó Cazorla Prieto, ${ }^{54}$ al señalar que el sistema tributario es un conjunto armónico e integrado de tributos, y no puede hablarse de un sistema tributario justo sin que también lo sean los distintos elementos que lo componen.

Ante los fuertes ataques que este artículo 31 de la Constitución Española viene sufriendo, según se ha puesto de relieve, no parece, siendo realistas, que queden más que estas dos opciones:

- O abolir sin más el mismo por inaplicable - ya ha señalado a este respecto Yebra Martul-Ortega ${ }^{55}$ que dicho precepto "no sirve para nada"-, para así adecuar la norma a la realidad.

- O exigir sin cortapisas ni ambigüedades el pleno cumplimiento de este precepto - si bien con toda seguridad sería oportuno y conveniente rebajar en algún grado sus exigencias, para así evitar que se pueda decir de él lo que Francis Bacon afirmaba del gremio de los metafísicos, de quienes señaló que se parecían a las estrellas en que "dan poca luz por estar demasiado altos"- por encima de la atención a cualquier interés económico que milite en contra, dictando, en suma, como señaló Villar Ezcurra, ${ }^{56}$ "actos que repercutan más en beneficio de la colectividad que en beneficio de los mercados".

Para esto último, que es lo único que considero correcto, sería necesario, desde luego, otra actitud menos conformista de los poderes legislativos de la que ahora existe, y que se concienticen, en suma, de que

efectos difícilmente compatibles con la idea de equidad, entre otros motivos por la carga distinta que reciben personas con un mismo nivel de ingreso pero diferente composición en cuanto a las fuentes de los mismos.

54 Cazorla Prieto, "Los principios constitucional-financieros en el nuevo orden jurídico", en Varios Autores, La Constitución española y las fuentes del derecho, Madrid, Dirección General de lo Contencioso del Estado, IEF, 1979, vol. I.

55 Yebra Martul-Ortega, "Origen, evolución, relevancia y futuro del principio de justicia tributaria", en Varios Autores, Memorias de los seminarios de derecho constitucional tributario 2005-2006, cit., nota 40.

56 Villar Ezcurra, "La armonización fiscal prevista por el derecho comunitario", RDFHP, núm. 252, 1999. 
el deber de contribuir proclamado en dicho precepto constitucional ${ }^{57}$ se configura, en su estructura normativa, como un mandato dirigido a ellos para que concreten tal deber y lo doten de sanción, y no como vinculación de la conducta de las personas, de conformidad con lo manifestado por Rodríguez Bereijo y Pérez de Ayala. ${ }^{58}$

En esta tarea dichos poderes legislativos tendrían que ser secundados de manera eficaz por las administraciones, ya que si bien es cierto que un mal sistema tributario no hay administración que lo remedie, no es infrecuente tampoco, ni mucho menos, que en bastantes ocasiones las administraciones tributarias contribuyen a agravar los problemas, en exceso, por desmesuras en el ejercicio de sus potestades, rigidices y "mezquindades", como ha escrito Casado Ollero. ${ }^{59}$

Y ello, por preocuparse la misma más por los resultados recaudatorios que por la aplicación de dicho sistema conforme a las exigencias de la justicia tributaria, circunstancia también denunciada, entre otros autores, por De Mita, Fedele, Aguallo Avilés, Kirchof ${ }^{60}$ — quien puso de relieve que el objeto de obtención de ingresos públicos aparece con una pobreza

57 Que no es una mera declaración programática, sino un auténtico mandato jurídico, fuente de derechos y de obligaciones, como la doctrina ha precisado — véase, por ejemplo, Lozano Serrano, Consecuencias de la jurisprudencia constitucional sobre el derecho financiero y tributario, Madrid, Civitas, 1990; Lasarte Álvarez, El sistema tributario actual y la situación financiera del sector público, Sevilla, Real Academia Sevillana de Legislación y Jurisprudencia, 1993, y Rodríguez Bereijo, "Los principios de la imposición en la jurisprudencia constitucional española”, REDF, Civitas, núm. 100, 1998- y el Tribunal Constitucional español ha mantenido en múltiples sentencias, entre otras, 4/1981, de 2 de febrero; 16/1982, de 28 de abril; 206/1992, de 30 de noviembre; 31/1994, de 31 enero; 47/1994, de 16 de febrero; 98/1994, de 11 de abril; 240/1994, de 20 de julio; 281/1994, de 17 de octubre; 307/1994, de 14 de noviembre; 88/1995, de 6 de junio; 112/1996, de 24 de junio; 182/1997, de 28 de octubre, y 169/2003, de 29 de septiembre.

58 Rodríguez Bereijo, "El deber de contribuir como deber constitucional. Su significado jurídico", REDF, Civitas, núm. 125, 2005, y Pérez de Ayala, Algunos problemas interpretativos del artículo 31.1 de la Constitución Española en un contexto jurisprudencial, Navarra, Thomson \& Civitas, Cuadernos Civitas, 2008.

59 Casado Ollero, op. cit., nota 39.

60 De Mita, "Capacità contributiva”, Rassegna Tributaria, núm. 2, 1987; Fedele, "I principi costituzionali e l'accertamento tributario", Riv. Dir. Fin. Sc. Fin., núm. 3, 1992; Aguallo Avilés, "Interés fiscal y estatuto del contribuyente", $R E D F$, núm. 80, 1993, y Kirchof, "La influencia de la Constitución alemana en su legislación tributaria", en Varios Autores, Garantías constitucionales del contribuyente, Valencia, Tirant lo Blanch, 1998. 
de contornos, no ofreciendo ningún leit-motiv como medida de una propuesta de justicia tributaria—, García Novoa y Moreno González. ${ }^{61}$

Entiéndase bien. No estoy propugnando, en modo alguno, que se desatienda la recaudación tributaria ni que, como corolario de ello, se desvíe la mirada y no se preste la debida atención a la necesidad de acabar con el fenómeno del fraude fiscal.

Al contrario, entiendo que la recaudación tributaria debe tener un papel relevante, ya que, como es obvio, sin la existencia de recursos económicos suficientes a disposición de los entes públicos éstos no podrían atender, de forma eficaz y satisfactoria, las cada vez más numerosas competencias que tienen que asumir, ni prestar, de manera adecuada, los muchos servicios que se les demandan por los ciudadanos.

Y, por otra parte, es también evidente que el fraude fiscal, como se ha declarado, entre otras, en las sentencias del Tribunal Constitucional español 110/1984, de 26 de noviembre; 76/1990, de 26 de abril; 214/1994, de 14 de julio; 50/1995, de 23 de febrero; 164/1995, de 13 de noviembre; $182 / 1997$, de 28 de octubre y 46/2000, de 17 de febrero, es un fenómeno del que se derivan graves consecuencias para la sociedad en su conjunto, por suponer una merma para los ingresos públicos, lo que afecta a la presión fiscal que soportan los contribuyentes cumplidores, al condicionar el nivel de calidad de los servicios públicos y las prestaciones sociales, y al distorsionar la actividad de los distintos agentes económicos, de tal modo que las empresas fiscalmente cumplidoras deben enfrentarse a la competencia desleal de las que no lo son, originándose con ello un fuerte elemento de inequidad de todo el sistema tributario.

61 Primar el interés recaudatorio por encima de los principios constitucionales tributarios es, además, de particular gravedad en el manejo y en la utilización de un instituto que, como el tributo, genera relaciones jurídicas de particular incidencia en el ámbito de los derechos públicos subjetivos, como bien indicó Casado Ollero, "Los fines no fiscales de los tributos", RDFHP, núm. 213, 1991. Con ello se ocasiona que a veces pueda llegar a hablarse, como hizo Vogel, "La hacienda pública y el derecho constitucional", HPE, núm. 59, 1979, del déficit constitucional del derecho financiero y tributario en lo que atañe y se refiere a la protección de los derechos fundamentales y de las libertades públicas. García Novoa, El principio de seguridad jurídica en materia tributaria, Madrid, Barcelona, Marcial Pons, 2000, y Moreno González, Constitución y leyes de «acompañamiento» presupuestario, Navarra, Thomson \& Aranzadi, Cizur Menor, 2004. 
No dejando de reconocer ambos extremos, estimo, sin embargo, que ni el interés recaudatorio ni la lucha contra el fraude fiscal pueden configurarse como categorías limitativas de derechos constitucionales.

Y ello porque aquellos fines, como bien ha expresado Pauner Chulvi, ${ }^{62}$ no son valores constitucionales preminentes, y tampoco pueden hacerse primar los aspectos en exclusiva recaudatorios, por importantes que los mismos sean - lo cual ya he reconocido que lo son- sobre los principios constitucionales recogidos en el artículo 31 de la Constitución Española, que tienen que ser de aplicación anterior a tales consideraciones recaudatorias, como ya escribió en su momento Calvo Ortega. ${ }^{63}$

Además de todo, ello es también necesario para defender de manera eficaz el contenido y alcance de dicho artículo 31 de la Constitución que el Tribunal Constitucional español deje de ser tan respetuoso y tan deferente con la discrecionalidad política de los poderes públicos como lo que hasta ahora, en general, ha sido en las materias económico-financieras.

Con ello, a mi juicio, este órgano ha ido mucho más allá de lo que una lógica y prudente actitud de judicial self restraint — esto es, de autocontención y autocontrol del Tribunal, de dejar margen al legislador para que con libertad desarrolle la Constitución, como entre otros muchos autores han señalado Blanco Valdés, Canosa Usera, Luis Vigo y Fernández Segado—64 demanda.

62 Pauner Chulvi, El deber constitucional de contribuir al sostenimiento de los gastos públicos, Madrid Centro de Estudios Políticos y Constitucionales, 2001.

63 Ilustrativa es a este respecto la Sentencia del Tribunal Constitucional español 164/1995, de 13 de noviembre, en la que se afirma que los temas de eficacia recaudatoria quedan, en rigor, "fuera del campo propio de las exigencias de un sistema tributario justo". Calvo Ortega, "Principios tributarios y reforma de la Hacienda municipal", en Varios Autores, La Ley de Reforma de las Haciendas Locales, Valladolid, Lex Nova, 1991, t. I.

64 Blanco Valdés, "Vigilar al legislador, vigilar al vigilante (Legitimidad del control de constitucionalidad y selfrestraint judicial en los orígenes del sistema norteamericano: un breve apunte histórico", en Varios Autores, La justicia constitucional en el Estado democrático, Valencia, Tirant lo Blanch, 2000; Canosa Usera, en Varios Autores, "Interpretación constitucional y voluntad democrática", Interpretación constitucional, México, Porrúa, UNAM, 2005; Luis Vigo, "Directivas de la interpretación constitucional", en Interpretación constitucional, México, Porrúa, UNAM, 2005, y Fernández Segado, "Reflexiones en torno a la interpretación de la Constitución", en Varios Autores, Interpretación constitucional, México, Porrúa, UNAM, 2005. 
Hay que convenir, con la generalidad de la doctrina, que el Tribunal Constitucional tan sólo debe declarar la inconstitucionalidad de una norma si contrastando ésta con la Constitución se aprecia un caso indudable de inconstitucionalidad, teniéndose que optar por la constitucionalidad de aquélla cuando el supuesto de posible vulneración del texto constitucional no se presente con meridiana y palpable claridad.

En esta última situación debe jugar el principio in dubio pro legislatore - cuyo alcance y contenido ha sido bien analizado por Ferreres Comella—, ${ }^{65}$ y que, en palabras de Troncoso Reigada, ${ }^{66}$ significa que el Tribunal Constitucional sólo puede declarar inconstitucionales tanto los supuestos de contradicción clara como los supuestos de incompatibilidad manifiesta entre un precepto constitucional y una Ley, teniéndose que decantar en los casos oscuros y difíciles (los hard cases) por la legitimidad de la opción normativa elegida por el legislador.

Con ser evidente y no discutible esta necesidad de optar por la legitimidad de las normas en los casos oscuros, este proceder puede conllevar, sin embargo, que el Tribunal Constitucional abdique de su cometido y de la eficaz realización de sus funciones, olvidándose así sus miembros de que deben essere giudici, non propaggini, esto es, jueces, y no esquejes o ramificaciones del poder, como todo acierto propugnó Zagrebelsky. ${ }^{67}$

A esto también se han referido, desde la estricta perspectiva del derecho tributario, entre otros autores, Sánchez Serrano, ${ }^{68}$ quien de manera muy crítica ha escrito que el Tribunal Constitucional español ha venido actuando más a modo, casi, de un órgano consultivo, de un órgano reforzador o legitimador del poder gubernamental, e incluso, a veces, de algunos de sus excesos inconstitucionales, que como un verdadero tribunal de garantías constitucionales, Fabra Valls, Palao Taboada, Sánchez

65 Ferreres Comella, Justicia constitucional y democracia, Madrid Centro de Estudios Políticos y Constitucionales, 1997.

66 Troncoso Reigada, "Método jurídico, interpretación constitucional y principio democrático", en Varios Autores, La justicia constitucional en el Estado democrático, Valencia, Tirant lo Blanch, 2000.

67 Zagrebelsky, Principî e voti. La Corte Costituzionale e la politica, Turín, Einaudi, 2005.

68 Sánchez Serrano, Tratado de derecho financiero y tributario constitucional, Madrid, Marcial Pons, 1997, t. I. 
Pedroche, Fernández Rodríguez y Falcón y Tella, ${ }^{69}$ quien ha indicado que la jurisprudencia constitucional española ha venido demostrando en materia tributaria un incomprensible temor a declarar la inconstitucionalidad de las normas enjuiciadas, no habiendo alcanzado, por ello, el grado de coherencia y rigor que sería deseable en el control del legislador tributario y en la protección de los derechos fundamentales. ${ }^{70}$

El resultado final es un déficit del control constitucional tributario, que, con cierta frecuencia, queda restringido al lamento de los votos particulares o a meras "amonestaciones" al legislador, como, entre otros, han puesto de relieve Herrera Molina y Malvárez Pascual. ${ }^{71}$

Esto es lo que, con toda probabilidad, ha conducido a Yebra MartulOrtega $^{72}$ a señalar que buscar la protección constitucional en la jurisprudencia puede resultar decepcionante, palabras a las que se suma López Espadafor ${ }^{73}$ cuando se refiere a las vagas y poco útiles referencias con las que a veces nos ha desilusionado o defraudado el Tribunal Constitucio-

69 Fabra Valls, op. cit., nota 46; Palao Taboada, "Nueva visita al principio de capacidad contributiva", REDF, núm. 124, 2004; Sánchez Pedroche, "El principio de capacidad económica", en Varios Autores, Memorias de los seminarios de derecho constitucional tributario 2005-2006, cit., nota 40; Fernández Rodríguez, "De la banalidad a la incoherencia y la arbitrariedad. Una crónica sobre el proceso, al parecer imparable, de degradación de la Ley", El Cronista del Estado Social y Democrático de Derecho, núm. 0, 2008, y Falcón y Tella, "El Guantánamo tributario. Una reflexión crítica sobre algunas medidas recientes y sobre la situación actual del sistema fiscal", El Cronista del Estado Social y Democrático de Derecho, núm. 2, 2009.

70 Así fue denunciado también en el voto particular, formulado por Rodríguez Bereijo y al que se adhirieron los magistrados González Campos, Viver Pi-Sunyer y Vives Antón, a la sentencia del Tribunal Constitucional 107/1996, de 12 de junio, al afirmarse en él que el principio de la deferencia hacia el legislador "determina una abdicación misma de nuestra propia jurisdicción constitucional sobre la ley".

71 Falcón y Tella, "El Guantánamo tributario. Una reflexión crítica sobre algunas medidas recientes y sobre la situación actual del sistema fiscal”, e id., "El Guantánamo tributario. Una reflexión crítica sobre algunas medidas recientes y sobre la situación actual del sistema fiscal", ambos en El Cronista del Estado Social y Democrático de Derecho, núm. 2, 2009.

72 Yebra Martul-Ortega, Constitución financiera española. Veinticinco años, Madrid, IEF, 2004; Yebra Martul-Ortega, op. cit., nota 54.

73 López Espadafor, "El valor racionalidad en la cuantía máxima del tributo", REDF, núm. 141, 2009. 
nal español, ${ }^{74}$ al que, por ello, son difíciles de aplicar las afirmaciones de Carmona Tinoco ${ }^{75}$ de que los jueces son los guardianes de la Constitución, funcionando como verdadero contrapeso de los órganos legislativo y ejecutivo para conservar el orden constitucional, impulsar su evolución y garantizar su eficacia, o las de Roa Jacobo ${ }^{76}$ cuando escribió que el juez constitucional es el medio para balancear, para restaurar el equilibrio entre poderes, entre un Ejecutivo desbordado y un Legislativo disminuido en cuanto a su legitimación.

Esta última precisión referida al Poder Legislativo es importante, ya que ello nos permite adentrarnos, siquiera sea de forma breve, en la crisis de otro principio constitucional: el de reserva de ley en materia tributaria, que también ha venido propiciada, en buena medida, por la globalización económica, puesto que son ya muchas las normas, o seudonormas, que se producen por completo al margen, y sin ninguna intervención, de los Parlamentos nacionales.

Me refiero a las nuevas medidas normativas que los anglosajones denominan soft-law o "legislación blanda" —fenómeno que, como ha in-

74 Véase también, en similar línea, Fernández Farreres, "Reflexiones sobre el futuro de la justicia constitucional española", en Varios Autores, El futuro de la justicia constitucional. Actas de las XII Jornadas de la Asociación de Letrados del Tribunal Constitucional, Madrid, Centro de Estudios Políticos y Constitucionales, 2007 —quien ha escrito que el relevante papel que la justicia constitucional española tuvo en sus primeros años de andadura, ha ido decayendo de manera progresiva hasta llegar a un punto crítico cuya superación demanda con urgencia la adopción de drásticas medidas reformadoras - y García Roca, "La experiencia de veinticinco años de jurisdicción constitucional en España", en Varios Autores, La reforma del Tribunal Constitucional. Actas del V Congreso de la Asociación de constitucionalistas de España, Valencia, Tirant lo Blanch, 2007, quien ha señalado que los años 2000 han iniciado una fase de "decadencia" de la jurisprudencia constitucional española, que contiene escasas referencias doctrinales novedosas, fruto de líneas de estudio prolongadas o de la indagación comparada, habiendo perdido buena parte de su interés doctrinal y, desde luego, de la capacidad de innovar el ordenamiento jurídico que antes tuvo, añadiendo que la jurisdicción constitucional ya no lidera el ordenamiento jurídico ni, en particular, el derecho constitucional y, en muchas materias, las elaboraciones científicas de la doctrina comienzan a ir por delante de ella.

75 Carmona Tinoco, "Algunos aspectos sobresalientes de la interpretación judicial constitucional”, en Varios Autores, Interpretación constitucional, cit., nota 64.

${ }^{76}$ Roa Jacobo, "Origen, evolución, relevancia y futuro de los principios constitucionales en materia tributaria”, en Varios Autores, Memorias de los seminarios de derecho constitucional tributario 2005-2006, cit., nota 40. 
dicado Tammes, ${ }^{77}$ presenta las características del derecho en cuanto a su pretendido efecto de influenciar en el deseo y de restringir la libertad de aquellos a quienes se dirige, pero que les falta algo en la naturaleza jurídica o vinculante del derecho tal y como lo conocemos en la vida cotidiana-, integradas por recomendaciones, declaraciones, acuerdos interinstitucionales, dictámenes, modus vivendi, comunicaciones, códigos de conducta, etcétera, ampliamente utilizadas por las instituciones y organizaciones internacionales, ${ }^{78}$ que son proclives a formular reglas y directrices, con el objetivo de establecer una serie de criterios o pautas de actuación que deben seguirse en la esfera internacional por los países, sean o no miembros de ellos, cuya finalidad última es que los mismos terminen convirtiéndose, por cauces indirectos pero que a la postre se han revelado muy eficaces, en legislación interna de tales países.

Por ello, en la actualidad, como ha escrito Tajadura Tejada, ${ }^{79}$ junto al derecho estatal, creado conforme a los principios democráticos del Estado constitucional, existe un inmenso corpus normativo producido extra muros del Estado que está integrado por numerosas reglas de dudosa condición democrática, y que obedecen y responden a exigencias de la

77 Tammes, "Soft Law", International and Comparative Law in Honour of Judge Erades, La Haya, Martinus Nijhoff, 1983.

78 Así sucede, por ejemplo, con el Banco Mundial; con el Fondo Monetario Internacional al negociar con los gobiernos estatales el otorgamiento de créditos internacionales, como han indicado Hammer y Owens, "Promoting Tax Competition", Tax Notes International, vol. 22, núm. 11, 2001; con la Organización para la Cooperación y el Desarrollo Económico, con sus modelos de convenios para evitar la doble imposición, que han contribuido de forma importante a la uniformidad de la fiscalidad internacional; y con la Organización Mundial del Comercio, según han señalado Almudí Cid et al., "La Organización Mundial del Comercio como límite a la potestad tributaria de los Estados, referencia a los regímenes estadounidenses de foreign sales corporation, extraterritorial income exclusión y a los artículos 32 y 34 LIS", $Q F$, núm. 12, 2002, y Valadés, "Problemas constitucionales de los flujos financieros internacionales", en Varios Autores, Constitución, Estado de las autonomías y justicia constitucional (Libro homenaje a Gumersindo Trujillo), cit., nota 10.

79 Tajadura Tejada, "Los principios constitucionales ante el desafío de la globalización", en Varios Autores, Derecho constitucional para el siglo XXI, Thomson \& Aranzadi, 2006, t. I. 
razón económica, ${ }^{80}$ siendo, además, las que operan e inciden de manera mucho más decisiva en el sentido y calidad de nuestras vidas.

Esto ha supuesto, como ha indicado García Prats, ${ }^{81}$ un progresivo acercamiento de las políticas tributarias, y ha conllevado, como ha resaltado Marcilla Córdoba, ${ }^{82}$ que la ley estatal a menudo desaparezca, sustituyéndose la actividad del Parlamento por "centros de producción normativa externos", como ha escrito Calderón Carrero, ${ }^{83}$ extremo éste también resaltado, entre otros muchos autores, por Xiol Ríos, ${ }^{84}$ cuando indicó que el fenómeno de la globalización ha puesto en cuestión las técnicas clásicas de obligatoriedad de las normas, el principio de legalidad y la eficacia territorial del poder jurídico del Estado, es decir, el modelo de Estado de derecho, obligando a abordar como realidad inexorable el lento y firme avance de una nueva metodología jurídica ajena a toda lógica conocida; y por Balaguer Callejón, F. ${ }^{85}$ quien, con carácter más general, ha señalado que el proceso de globalización ha situado a los Estados en una posición de debilidad (también para el desarrollo de sus propias políticas internas) frente a otros agentes, en especial frente a las grandes compañías multinacionales.

\section{BIBLIOGRAFÍA}

Aguallo AVILÉS, "Interés fiscal y estatuto del contribuyente", $R E D F$, núm. 80, 1993.

80 Este proceder, como bien indicó Gutmann, "Globalizzazione e giustizia tributaria”, Diritto e Practica Tributaria Internazionale, núm. 3, 2002, “...invece di essere l'espressione di un principio de giustizia discusso in Parlamento, si presenta come una soluzione imposta dal mondo economico", añadiendo que: "Questa evoluzione considerata sotto il profilo dell'etica politica pone molto chiaramente il problema della legittimità democrática del tributo in un mondo in cui i paesi non godono più della libertà delle loro scelte fiscali".

81 García Prats, Cooperación administrativa internacional en materia tributaria. Derecho tributario global, IEF, doc. núm. 3, 2007.

82 Marcilla Córdoba, Racionalidad legislativa. Crisis de la ley y nueva ciencia de la legislación, Madrid, Centro de Estudios Políticos y Constitucionales, 2005.

83 Calderón Carrero, op. cit., nota 30.

84 Xiol Ríos, op. cit., nota 44.

85 Balaguer Callejón, F., "El Tratado de Lisboa en el diván. Una reflexión sobre estatalidad, constitucionalidad y Unión Europea”, REDC, núm. 83, 2008. 
Almudí Cid, Planificación fiscal internacional a través de sociedades holding, IEF, doc. núm. 24, 2006.

- et al., "La Organización Mundial del Comercio como límite a la potestad tributaria de los Estados, referencia a los regímenes estadounidenses de foreign sales corporation, extraterritorial income exclusión y a los artículos 32 y 34 LIS", $Q F$, núm. 12, 2002.

ARANA LANDÍN, "Los pretendidos principios de simplificación y neutralidad como justificación de base en las distintas reformas del IRPF", Nueva Fiscalidad, núm. 2, 2007.

Avi-YonAH, "Globalisation, Tax Competition, and the Fiscal Crisis of the Welfare State", Harvard Law Review, vol. 113, núm. 7, 2000.

Balaguer CAllejón, F., "El Tratado de Lisboa en el diván. Una reflexión sobre estatalidad, constitucionalidad y Unión Europea", $R E D C$, núm. 83, 2008.

BARQUERO ESTEVAN, La función del tributo en el Estado social y democrático de derecho, Madrid, Centro de Estudios Políticos y Constitucionales, 2002.

BLANCO VALDÉS, "Vigilar al legislador, vigilar al vigilante (Legitimidad del control de constitucionalidad y selfrestraint judicial en los orígenes del sistema norteamericano: un breve apunte histórico", en VARIOS AUTORES, La justicia constitucional en el Estado democrático, Valencia, Tirant lo Blanch, 2000.

BRACEWELl-Mines, "Tax Competition: Harmful or Beneficial”, Intertax, núm. 3, 1999.

Bustos GisBerT y ARTÉs CASELles, "Una valoración de la última reforma del Impuesto sobre la Renta de las Personas Físicas", Justicia y derecho tributario. Libro homenaje al prof. Julio Banacloche Pérez, Madrid, La Ley, 2008.

CAAMAÑo ANIDO y CALDERÓN CARRERO, "Globalización económica y poder tributario: ¿hacia un nuevo derecho tributario?”, REDF, núm. 114, 2002.

CALDERÓN CARRERO, La incidencia de la globalización en la configuración del ordenamiento tributario del siglo XXI, IEF, doc. núm. 20, 2006.

CALIFANO, "Controlled Foreign Companies: esperienze tributarie nazionali e principi del Trattato", en VARIOS AUTORES, Lo stato della fiscali- 
tà nell'Unione europea. L'esperienza e l'efficacia dell'armonizzazione, Bologna, Ministero dell'Economia e delle Finanze, t. II, 2003.

CAlvo ORTEGA, "Principios tributarios y reforma de la hacienda municipal", en VARIOS AUTORES, La Ley de Reforma de las Haciendas Locales, Valladolid, Lex Nova, t. I, 1991.

CANOSA USERA, "Interpretación constitucional y voluntad democrática", en Varios Autores, Interpretación constitucional, México, Porrúa, UNAM, 2005.

CARMONA TINOCO, "Algunos aspectos sobresalientes de la interpretación judicial constitucional", en VARIOS AUTORES, Interpretación constitucional, México, Porrúa, UNAM, 2005.

CARRASCO GONZÁLEZ, El principio democrático de autoimposición en la producción normativa de la Unión Europea, Valencia, Tirant lo Blanch, 2005.

CASAdo Ollero, “Ámbito de aplicación de los principios de justicia tributaria", en VARIOS AutORES, Memorias de los seminarios de derecho constitucional tributario 2005-2006, México, Suprema Corte de Justicia de la Nación, 2007.

, "Deber de contribuir e Impuesto sobre la Renta de las Personas Físicas en la jurisprudencia constitucional", en VARIOS AUTORES, Manual del Impuesto sobre la Renta de las Personas Físicas, Madrid, IEF, Escuela de la Hacienda Pública, 2005. 1991.

CAZORLA PRIETO, "Los principios constitucional-financieros en el nuevo orden jurídico", en VARIOS AUTORES, La Constitución Española y las fuentes del derecho, Madrid, Dirección General de lo Contencioso del Estado, IEF, 1979, vol. I.

CHICO DE LA CÁMARA, “¿Competencia fiscal 'lesiva' o 'beneficiosa’? un argumento adicional para la armonización de la imposición directa de los no residentes", RCT, núm. 280, 2006.

CORDERO GONZÁLEZ, "El intercambio de información sobre las rentas del capital mobiliario en la Unión Europea", en VARIOS AUTORES, Estudios de derecho financiero y tributario en homenaje al prof. Calvo Ortega, Valladolid, Lex Nova, 2005, t. I.

CRUZ PADIAL, "Sistema tributario: su falta de adecuación al contexto actual originado por el proceso de globalización económica", $N F$, núm. 9, 2007. 
EASSON, "Fiscal Degradation and the Inter-nation Allocation of Tax Jurisdiction", EC Tax Review, 1996-3, Kluwer, The Netherlands, 1996.

Cubero Truyo, "La función del I.R.P.F. en el sistema tributario según la jurisprudencia constitucional", RIF, núm. 27, 1998.

DE KAM y CLARK, "A World of Taxes: the OECD Reports on Tax Trends", Tax Notes International, vol. 16, núm. 12, 1998.

DE MitA, “Capacità contributiva”, Rassegna Tributaria, núm. 2, 1987.

DE VEGA, "Mundialización y derecho constitucional: la crisis del principio democrático en el constitucionalismo actual", REP, núm. 100, 1998.

DÍAZ, E., "Estado de derecho y sociedad democrática", en VARIOS AUTORES, Constitución, Estado de las autonomías y justicia constitucional. (Libro homenaje a Gumersindo Trujillo), Valencia, Tirant lo Blanch, 2005.

EISENSTEIN, Las ideologías de la imposición, Madrid, IEF, 1983.

ENRICH, "Saving the States from Themselves: Commerce Clause Constraints on State Tax Incentives", Harward Law Review, núm. 2, 1996.

FABRA VALLS, "Solidaridad y derecho financiero en una sociedad neocompetitiva", REDF, núm. 120, 2003.

FALCÓN y TELLA, "El Guantánamo tributario. Una reflexión crítica sobre algunas medidas recientes y sobre la situación actual del sistema fiscal", El Cronista del Estado Social y Democrático de Derecho, núm. 2, 2009.

FANTOZZI, "Il sistema tributario tra libertà di iniziativa economica e solidarietà sociale", Dir. Ec., núm. 3, 1994.

FEDELE, "I principi costituzionali e l'accertamento tributario", Riv. Dir. Fin. Sc. Fin., núm. 3, 1992.

FERNÁNDEZ FARRERES, "Reflexiones sobre el futuro de la justicia constitucional española", en VARIOS AUTORES, El futuro de la justicia constitucional. Actas de las XII Jornadas de la Asociación de Letrados del Tribunal Constitucional, Madrid, Centro de Estudios Políticos y Constitucionales, 2007.

FERNÁNDEZ JUNQUERA, "El IRPF y los principios constitucionales de justicia tributaria: una relación controvertida", en VARIOS AUTORES, Estudios jurídicos en memoria de don César Albiñana García-Quintana, Madrid, IEF, 2008, vol. II. 
FERNÁNDEZ ORTE, "El principio de capacidad económica y el nuevo IRPF", RTT, núm. 80, 2008.

FERNÁNDEZ RODRÍGUEZ, "De la banalidad a la incoherencia y la arbitrariedad. Una crónica sobre el proceso, al parecer imparable, de degradación de la ley", El Cronista del Estado Social y Democrático de Derecho, núm. 0, 2008.

FERNÁNDEZ SEGADO, "Reflexiones en torno a la interpretación de la Constitución", en VARIOS AUTORES, Interpretación constitucional, México, UNAM, Porrúa, 2005.

FERREIRO LAPATZA, "Simplificación; base imponible y renta empresarial", $Q F$, núm. 21, 2006.

FERRERES COMELla, Justicia constitucional y democracia, Madrid Centro de Estudios Políticos y Constitucionales, 1997.

GARCÍA LUQUE, "La actividad financiera del Estado social globalizado. (La prevención de gastos públicos y el tributo de tercera generación)", REDF, núm. 131, 2006.

GARCÍA NovOA, El principio de seguridad jurídica en materia tributaria, Madrid, Barcelona, Marcial Pons, 2000.

, "Reflexiones sobre la influencia de la globalización en los principios tributarios", Revista Argentina de Derecho Tributario, Universidad Austral Tax Law Review, La Ley, núm. 5. Este trabajo también está publicado en VARIos Autores, Direitto Tributário Internacional, São Paulo, Quarter Latin, 2003.

GARCÍA PRATS, "Incidencia del derecho comunitario en la configuración jurídica del derecho financiero (II): políticas comunitarias con incidencia sobre el derecho financiero", RDFHP, núm. 260, 2001.

- Cooperación administrativa internacional en materia tributaria. Derecho tributario global, IEF, doc. núm. 3, 2007.

GARCÍA ROCA, "La experiencia de veinticinco años de jurisdicción constitucional en España", en VARIOS AUTORES, La reforma del Tribunal Constitucional. Actas del V Congreso de la Asociación de constitucionalistas de España, Valencia, Tirant lo Blanch, 2007.

GoDOI, Fraude a la ley y conflicto en la aplicación de las leyes tributarias, Madrid, IEF, 2005.

GONZÁlEZ GARCÍA, El fraude a la Ley tributaria en la jurisprudencia, Navarra, Aranzadi, 2001.

Gorosabel RebolledA, “El nuevo IRPF”, RIF, núm. 83, 2007. 
Grau Ruiz y Herrera Molina, “La armonización fiscal: límites y alternativas", Impuestos, 2002, t. I.

GUTIÉRREZ LOUSA y RODRÍGUEZ ONDARZA, Las consecuencias fiscales de la globalización, IEF, doc. núm. 8, 2007.

Gutmann, "Globalizzazione e giustizia tributaria", Diritto e Pratica Tributaria Internazionale, núm. 3, 2002.

HAGEN y SORENSEN, "Taxation of the Self-employed under a Dual Income Tax", en VArios AutOres, Towards a Dual Income Tax?, Londres, Kluwer, 1996.

HAMMER y OWENS, "Promoting tax competition", Tax Notes International, vol. 22, núm. 11, 2001.

FALCÓN y TELLA, "El Guantánamo tributario. Una reflexión crítica sobre algunas medidas recientes y sobre la situación actual del sistema fiscal", El Cronista del Estado Social y Democrático de Derecho, núm. 2, 2009.

JIMÉNEZ AMBEL, "El alcance confiscatorio como límite del sistema tributario español”, RVHP, núm. 7, 1989.

KIRCHOF, "La influencia de la Constitución alemana en su legislación tributaria", en VARIOS AUTORES, Garantías constitucionales del contribuyente, Valencia, Tirant lo Blanch, 1998.

LAMAGRANDE, "Los desafíos de la administración tributaria frente a la globalización", CT, núm. 87, 1998.

LARRAZ, "Metodología aplicativa del derecho tributario", Revista de Derecho Privado, Madrid, 1952.

LASARTE ÁlVAREZ, El sistema tributario actual y la situación financiera del sector público, Sevilla, Real Academia Sevillana de Legislación y Jurisprudencia, 1993.

LEJEUNE VALCÁRCEL, "Aproximación al principio constitucional de igualdad tributaria", en VARIOS AUTORES, Seis estudios sobre derecho constitucional e internacional tributario, Madrid, Derecho Financiero, 1980.

Lodin, "The Competitiveness of EU Tax Systems", European Taxation, mayo de 2001.

LÓPEZ ESPADAFOR, "El valor racionalidad en la cuantía máxima del tributo", REDF, núm. 141, 2009.

LOZANO SERRANO, Consecuencias de la jurisprudencia constitucional sobre el derecho financiero y tributario, Madrid, Civitas, 1990. 
LUIS VIGO, "Directivas de la interpretación constitucional", en VARIOS AUTORES, Interpretación constitucional, México, Porrúa, UNAM, 2005.

MAGRANER MORENO y MARTÍN LÓPEZ, "Normativa comunitaria en ayudas de estado versus competencia fiscal perjudicial", Cuadernos de Integración Europea, núm. 4, 2006.

MALDONADO GARCÍA-VERDUGO, "Ejercicios sobre competencia fiscal perjudicial en el seno de la Unión Europea y de la OCDE: semejanzas y diferencias", $C T$, núm. 97, 2001.

FALCÓN y TELLA, "El Guantánamo tributario. Una reflexión crítica sobre algunas medidas recientes y sobre la situación actual del sistema fiscal”, El Cronista del Estado Social y Democrático de Derecho, núm. 2, 2009.

MARCILla CóRdoba, Racionalidad legislativa. Crisis de la ley y nueva ciencia de la legislación, Madrid, Centro de Estudios Políticos y Constitucionales, 2005.

MARTÍN JimÉNEZ y CALDERÓN CARRERO, “Jurisprudencia del Tribunal de Justicia de las Comunidades Europeas en materia de IRPF", en VARIOS AUTORES, Manual del Impuesto sobre la Renta de las Personas Físicas, Madrid, IEF, 2005.

MARTín LÓPEZ, Competencia fiscal perjudicial y ayudas de Estado en la Unión Europea, Valencia, Tirant lo Blanch, 2006.

MARTÍN QUERALT, "Constitución Española y derecho financiero", HPE, núm. 63, 1980.

MARTÍNEZ GARCÍA-MONCÓ, Libre circulación de capitales en la Unión Europea: problemas tributarios, Madrid, Civitas, 1999.

MCLURE, JR., "Método legislativo, judicial, de soft law y cooperativo para armonizar los impuestos sobre sociedades en los Estados Unidos y en la Unión Europea", REDF, núm. 136, 2007.

MERINO JARA, "Fiscalidad y Unión Europea", JT, 1996, t. III.

MIRANDA PÉREZ, "El principio constitucional de no confiscatoriedad en materia fiscal", JT, t. III, 1997.

MORENO FERNÁNDEZ, "Del deber constitucional de pagar un tributo a la responsabilidad patrimonial del Estado-Legislador", El Cronista del Estado Social y Democrático de Derecho, núm. 3, 2009.

Moreno GonzÁlez, Constitución y leyes de «acompañamiento» presupuestario, Navarra, Thomson \& Aranzadi, Cizur Menor, 2004. 
NAVAS VÁZQUEZ, “Algunos fallos del sistema tributario", en VARIOS AUTORES, Estudios jurídicos en memoria de don César Albiñana GarcíaQuintana, Madrid, IEF, 2008, vol. II.

—, "Sistema tributario", $Q F$, núm. 6, 2008.

ORÓN MORATAL, "Consecuencias de la integración en las Comunidades Europeas sobre el derecho financiero y tributario", $R E D F$, núm. 97, 1998.

et al., Poder tributario y competencia fiscal: en especial el caso de La Rioja, Logroño, Instituto de Estudios Riojanos, 2003.

OWENS, "Emerging Issues in Tax Reform: the Perspective of an International Bureaucrat", Tax Notes International, vol. 15, núm. 25, 1997.

_- "Tax Systems in the New Millennium", Liber Amicorum SvenOlof Lodin, Kluwer, The Hague, 2001.

PALAO TABOADA, "Nueva visita al principio de capacidad contributiva", $R E D F$, núm. 124, 2004.

PATÓN GARCÍA, "Consideraciones acerca de la justicia financiera en los albores del siglo XXI", en VARIOS AUTORES, Estudios jurídicos en memoria de Don César Albiñana García-Quintana, Madrid, IEF, 2008, vol. II.

PAUNER CHULVI, El deber constitucional de contribuir al sostenimiento de los gastos públicos, Madrid Centro de Estudios Políticos y Constitucionales, 2001.

PÉREZ DE AYALA, Algunos problemas interpretativos del artículo 31.1 de la Constitución Española en un contexto jurisprudencial, Navarra, Thomson \& Civitas, Cuadernos Civitas, 2008.

RhAn y RUGy, "Threats to Financial Privacy and Tax Competition", Policy Analysis, núm. 10, 2003.

ROA JACOBO, "Origen, evolución, relevancia y futuro de los principios constitucionales en materia tributaria", en VARIOS AUTORES, Memorias de los seminarios de derecho constitucional tributario 2005-2006, México, Suprema Corte de Justicia de la Nación, 2007.

RODRÍGUEz BEREIJO, "El sistema tributario en la Constitución (los límites del poder tributario en la jurisprudencia del Tribunal Constitucional)", REDC, núm. 36, 1992.

, "Los principios de la imposición en la jurisprudencia constitucional española", REDF, núm. 100, 1998. 
_, "El deber de contribuir como deber constitucional. Su significado jurídico", REDF, núm. 125, 2005.

Rolle, "Mercato interno e fiscalità diretta nel Trattato di Roma e nelle recenti iniziative della Commissione europea", Diritto e Pratica Tributaria, núm. 2, 1999.

Ruibal Pereira, "Fraude y competencia fiscal desleal en el proceso de armonización europea", en VARIOS AUTORES, Temas de derecho penal tributario, Madrid, Barcelona, Marcial Pons, 2000.

RUIZ-HUERTA CARBONELL, "Vigencia y operatividad del principio de la no confiscatoriedad de los tributos en el ordenamiento español", $C T$, núm. 64, 1992.

SÁNCHEZ PEDROCHE, "El principio de capacidad económica", en VARios Autores, Memorias de los seminarios de derecho constitucional tributario 2005-2006, México, Suprema Corte de Justicia de la Nación, 2007.

SÁnCHEZ SERRANO, Tratado de derecho financiero y tributario constitucional, Madrid, Marcial Pons, 1997, t. I.

SANTACROCE, "La política di concorrenza nella UE", en VARIOS AUTORES, Lo stato della fiscalità nell'Unione europea. L'esperienza e l'efficacia dell'armonizzazione, Bologna, Ministero dell'Economia e delle Finanze, 2003 t. II.

TAJADURA TEJADA, "Los principios constitucionales ante el desafío de la globalización”, en VARIOS AUTORES, Derecho constitucional para el siglo XXI, Thomson \& Aranzadi, 2006, t. I.

TAMMES, "Soft Law", International and Comparative Law in Honour of Judge Erades, La Haya, Martinus Nijhoff, 1983.

TANZI, Taxation in a Integrating World, Washington, IMF, 1995.

TIPKE, "El derecho tributario constitucional en Europa", Revista Euroamericana de Estudios Tributarios, núm. 5, 2000.

TRONCOSO REIGADA, "Método jurídico, interpretación constitucional y principio democrático", en VARIOS AUTORES, La justicia constitucional en el Estado democrático, Valencia, Tirant lo Blanch, 2000.

VALADÉS, "Problemas constitucionales de los flujos financieros internacionales", en VArios Autores, Constitución, Estado de las Autonomías y justicia constitucional (Libro homenaje a Gumersindo Trujillo), Valencia, Tirant lo Blanch, 2005.

VARONA ALABERn, "Temas selectos sobre el ámbito de aplicación de los principios de justicia tributaria", en VARIOS AUTORES, Memorias de los 
seminarios de derecho constitucional tributario 2005-2006, México, Suprema Corte de Justicia de la Nación, 2007.

VILAR MAYER, "Planificación fiscal indebida y el conflicto en la aplicación de la norma tributaria española", RCT, núm. 273, 2005.

VILLAR EZCURRA, "Exigencias del derecho comunitario a la metodología del derecho financiero y tributario", CT, núm. 100, 2001.

—_ "La armonización fiscal prevista por el derecho comunitario", RDFHP, núm. 252, 1999.

VOGEL, "La hacienda pública y el derecho constitucional", $H P E$, núm. 59, 1979.

WoLf, "Does Globalisation Render States Impotent?", British Tax Review, núm. 5, 2000.

Xiol Ríos, "Legitimidad y legalidad en la sociedad española del siglo XXI", en VArios Autores, Parlamento y Poder Judicial. XIII Jornadas de la Asociación Española de Letrados de Parlamentos, Madrid, Tecnos, 2007.

Yebra Martul-Ortega, Constitución financiera española. Veinticinco años, Madrid, IEF, 2004.

—_ "Origen, evolución, relevancia y futuro del principio de justicia tributaria", en VARIOS AUTORES, Memorias de los seminarios de derecho constitucional tributario 2005-2006, México Suprema Corte de Justicia de la Nación, 2007.

Zagrebelsky, Principi e voti. La Corte Costituzionale e la politica, Turín, Einaudi, 2005. 